\title{
"AKU MAU BANTU KARENA AKU MERASA DEKAT": PERAN IDENTITY FUSION SEBAGAI MODERATOR DALAM PENGARUH JARAK SOSIAL TERHADAP PERILAKU BERDONASI KEPADA LEMBAGA AMAL
}

\author{
Giovanno Rachmat*, Amarina Ariyanto, \& Whinda Yustisia \\ Fakultas Psikologi, Universitas Indonesia \\ Email*: giovannorachmat@gmail.com
}

\begin{abstract}
Abstrak
Penelitian terdahulu menunjukkan bahwa jarak sosial memiliki peranan penting dalam menjelaskan perilaku donasi. Hal ini didasari pada ide bahwa seseorang akan lebih mau berdonasi pada orang dengan keanggotaan kelompok yang sama. Namun kenyataannya, individu memiliki tingkat kedekatan dengan kategorisasi sosial tertentu. Bisa saja, secara objektif individu memiliki latar belakang keanggotaan kelompok yang sama dengan target donasi. Namun, secara subjektif individu merasa identitas personalnya tidak terlalu dekat dengan kategorisasi sosial tersebut sehingga individu tidak terlalu merasa dekat dengan target donasi dan pada gilirannya tidak meningkatkan kecenderungan donasi. Penelitian ini berupaya memahami lebih jauh pengaruh kedekatan sosial dengan perilaku donasi dengan mempertimbangkan peran identity fusion sebagai moderator. Penelitian eksperimen dilakukan pada 110 mahasiswa dengan kriteria mahasiswa aktif S1 Universitas Indonesia dan beragama Islam $(M=19,87, S D=1,10)$. Penelitian ini menggunakan 2 (Jarak sosial: besar vs. kecil) $\times 2$ (identity fusion: kuat vs. lemah) between subject design. Hasil analisis menunjukkan bahwa 15,30\% varians perilaku berdonasi dapat dijelaskan oleh jarak sosial, $F(5,104)=3.756, p=0,04)$, meski jarak sosial tidak memiliki significant unique effect terhadap perilaku berdonasi. Namun, terdapat pengaruh interaksi yang signifikan antara jarak sosial dan identity fusion $(b=0,456, S E=0,187,95 \% \mathrm{Cl}[0,086,0,826], t=2,443, p=$ 0,016). Secara spesifik, jarak sosial mempengaruhi perilaku berdonasi secara signifikan ketika tingkat identity fusion rendah $(b=-0,704, S E=0,268,95 \% \mathrm{Cl}[-1,235,-0,173], t=-$ 2,631, $p=0,010$ ) tetapi tidak ketika tingkat identity fusion tinggi.
\end{abstract}

Kata kunci: perilaku donasi; identity fusion; jarak sosial; mahasiswa

\begin{abstract}
Previous studies showed that social distance has an important role in explaining donation behavior. This is built on the notion that a person is more likely to give donation to someone with similar group memberships. However, each person has different levels of proximity (or distance) towards the target with group memberships. Objectively, they may have the same social background. Subjectively, however, the person may perceive that their personal identity not closely related to the social group in common that might cause to perceive a distant to the target and cosequently would not be able to increase donation behavior. This study attempted to further understand the relationship of social distance with donation behavior by examining the fusion identity as moderator. One hundred and ten undergraduate Muslim students of Universitas Indonesia $(M=19.87, S D=1.10)$ were recruited as participants. We used 2 (social distance: near vs. distant) $x 2$ (identity fusion: high vs. low) between subject design. The analysis showed that $15.30 \%$ variance donation behavior can be explained by social distance, $F(5,104)=3.756, p=0.04$, though social
\end{abstract}


distance did not have a significant unique effect towards donation behavior. However, there was a significant interaction effect between social distance and identity fusion $(b=$ $0.456, S E=0.187,95 \% \mathrm{Cl}[0.086,0.826], t=2.443, p=0.016268,95 \% \mathrm{Cl}[-1.235,-0.173]$, $t=-2.631, p=0.010)$ but not when the identity fusion is high.). Specially, social distance affected donation behavior when the identity fusion is low $(b=-0.704, S E=0$.

Keywords: donating behavior; identity fusion; social distance; undergraduate students

\section{Pendahuluan}

Sebagai mahluk sosial, manusia melakukan sesuatu bukan hanya untuk dirinya sendiri namun juga untuk orang lain (Dunfield, 2014), misalnya menolong sesama. Perilaku ini dikenal sebagai perilaku prososial, yang merupakan perbuatan yang bermanfaat bagi orang lain dan dilakukan secara sukarela (voluntary action; Pryor, Reeder, Monroe, \& Patel, 2010). Ada banyak ragam perilaku prososial, salah satunya adalah berdonasi. Secara umum, perilaku berdonasi merupakan proses yang melibatkan beberapa pihak, baik antara individu sebagai donatur dan sebuah lembaga amal atau perorangan yang menjadi sasaran donasi (donation target). Studi terdahulu menunjukkan bahwa salah satu faktor yang dapat mempengaruhi perilaku berdonasi adalah adanya kesamaan latar belakang sikap, karakteristik, ataupun kepribadian. Dengan latar belakang yang sama, 'koneksi' target dan partisipan dapat terbentuk. Koneksi ini disebut sebagai in-group belongingness (Liviatan, Trope, \& Liberman, 2008).

Selain meningkatkan in-group belongingness, kesamaan katar belakang target dan donator juga dapat memperkecil jarak psikologis antara target dengan donator (Liberman, Trope, \& Stephan, 2007), misalnya jarak sosial (social distance; contoh: asal kelompok). Dalam salah satu eksperimennya, Ein-Gar dan Levontin (2013) meneliti pengaruh social distance (yang berikutnya akan penulis sebut dengan "jarak sosial") terhadap keinginan untuk berdonasi, yang dimoderasi oleh sasaran donasi (donation target). Dalam studi tersebut dijelaskan bahwa sebagian besar lembaga amal menggunakan populasi spesifik sebagai daya tarik (yaitu calon penerima donasi) dalam penggalangan dana mereka, karena dianggap dapat mengaktifkan (trigger) rasa empati dan simpati calon donatur sehingga mereka mau donasi. Efek ini disebut sebagai identifiable victim effect (Small, Loewenstein, \& Slovic, 2007). Namun Ein-Gar dan Levontin (2013) menganggap pendekatan tersebut kurang efektif; hampir semua lembaga amal menggunakan cara yang sama, sehingga para calon donatur dapat merasa 'kebal' (emotionally immune), yang dapat menyebabkan calon donatur enggan untuk berdonasi.

Bergerak dari asumsi tersebut, EinGar dan Levontin (2013) menduga bahwa lembaga amal akan menerima jumlah donasi yang lebih banyak ketika appeal dari sebuah penggalangan dana adalah lembaga amal itu sendiri, dibandingkan dengan populasi yang spesifik seperti seorang wanita atau pria. Untuk membuktikan dugaan tersebut, sebuah penelitian eksperimen desain faktorial 2 (jarak sosial: besar vs. kecil) $\times 2$ (donation target: specific vs. abstract) between subject dilakukan. Manipulasi target donasi dilakukan dengan memberi informasi kepada partisipan bahwa donasi disalurkan langsung kepada populasi spesifik pada kelompok specific donation target, dan kepada lembaga amal pada kelompok abstract donation target. Untuk manipulasi jarak sosial, variasi jenis kelamin target penerima donasi diberikan; dalam kondisi jarak sosial tinggi, partisipan dipasangkan pada donation target dengan jenis kelamin yang berbeda, sedangkan dalam kondisi jarak sosial kecil jenis kelaminnya 
disamakan. Setelah membaca, partisipan diminta untuk memberitahu jumlah uang yang ingin didonasikan kepada donation target pada masing-masing kelompok. Hasil studi menunjukkan bahwa partisipan lebih ingin memberikan donasinya kepada lembaga amal ketika partisipan merasa 'jauh' terhadap populasi yang membutuhkan. Dengan kata lain, individu lebih ingin memberikan donasinya kepada lembaga amal ketika jarak sosial antara individu terhadap populasi yang membutuhkan tinggi. Berdasarkan temuan tersebut, disimpulkan bahwa jarak sosial mempunyai pengaruh terhadap intensi berdonasi.

Meski studi Ein-Gar dan Levontin (2013) membuktikan bahwa intensi berdonasi dapat dipengaruhi oleh jarak sosial, studi tersebut masih memiliki beberapa keterbatasan. Pertama, EinGar dan Levontin (2013) hanya mengukur intensi berdonasi partisipan, sehingga kurang dapat sepenuhnya menggambarkan perilaku berdonasi individu sepenuhnya dalam konteks donasi ke lembaga amal. Partisipan juga dapat mengisi sebesar apapun jumlah uang yang ingin didonasikan tanpa menghitung jumlah uang yang dimilikinya, sehingga ada kemungkinan data yang didapat kurang akurat dan tepat. Kedua, penelitian ini baru mempertimbangkan kesamaan identitas donator dan target donasi saja. Jika identitas sosial (gender) berbeda, maka jarak sosial donator dan penerima donasi dikatakan jauh. Padahal, dalam kondisi tertentu bisa saja persepsi jarak sosial tersebut tidak menjadi masalah bagi donator, misalnya ketika donatur sendiri tidak sangat dekat dengan identitas sosial yang menjadi total ukur jauh atau dekatnya jarak sosial antara dirinya dengan penerima donasi. Katakanlah, misalnya, seorang donator beretnis Jawa secara objektif memiliki persamaan identitas etnis dengan penerima donasi. Namun demikian, jika donator tersebut tidak merasa dekat dengan etnis Jawa-nya, apakah kesamaan identitas sosial sebagai orang
Jawa tersebut juga cukup mampu membuat donator merasa dekat dengan penerima donasi?

Bergerak keterbatasan-keterbatasan tersebut, penelitian ini berupaya untuk melakukan penelitian lanjutan untuk melihat efek jarak sosial terhadap perilaku berdonasi. Namun, berbeda dengan studi sebelumnya, di sini peneliti akan mengukur perilaku yang dapat diobservasi langsung (overt behavior) sebagai variabel terikat. Lebih lanjut, kami juga mengukur pengaruh kedekatan identitas personal donator dengan identitas sosial-nya yang menjadi fokus pembanding kesamaan atau perbedaan latar belakang donator dan penerima donasi. Peleburan identitas personal dan identitas sosial ini dikenal sebagai fusion identity. Identity Fusion adalah meleburnya (immersed) identitas individu dengan identitas kelompok sehingga menjadi satu kesatuan yang mendalam (visceral oneness; Fredman dkk., 2015; Swann \& Buhrmester, 2015). Ketika individu telah melebur, identitas ingroup menjadi identitas individu; individu tidak kehilangan identitasnya sebagai seorang individu, namun telah menjadi satu dengan ingroup. Dengan kata lain, 'aku adalah kaumku', dan 'kaumku adalah aku'.

Penelitian terdahulu menunjukkan bahwa individu yang telah 'melebur' (fused) dengan ingroup lebih tergerak untuk rela berkorban demi ingroup, bahkan sampai rela mengorbankan nyawa (self sacrifice; Swann, Gómez, Seyle, Morales, \& Huici, 2009; Swann, Gómez, Dovidio, Hart, \& Jetten, 2010a; Swann dkk., 2014a). Selain tindakan rela berkorban, individu juga lebih tergerak untuk membantu anggota ingroup, salah satunya memberikan donasi berupa uang. Lebih lanjut, donasi yang diberikan kepada anggota ingroup lebih besar dibandingkan kepada outgroup (Swann, Gómez, Huici, Morales, \& Hixon, 2010b).

Berdasarkan hasil penelitian sebelumnya yang telah dijelaskan, penulis memiliki beberapa hipotesis penelitian. Pertama, jarak sosial dan 
identity fusion memiliki pengaruh yang signifikan terhadap perilaku berdonasi. Partisipan dalam kelompok kontrol (socially near) dengan penerima donasi akan memberikan donasi yang lebih banyak dibandingkan partisipan dalam kelompok eksperimen (socially distant). Lebih lanjut, partisipan dengan tingkat identity fusion yang tinggi juga akan berdonasi lebih banyak dibandingkan dengan partisipan dengan tingkat identity fusion yang rendah. Dengan demikian, donasi tertinggi akan diberikan oleh partisipan dalam kelompok kontrol dan memiliki tingkat identity fusion yang tinggi, sedangkan donasi terendah akan diberikan oleh partisipan dalam kelompok eksperimen dan tingkat identity fusion yang tinggi.

Kedua, interaksi antara identity fusion dengan jarak sosial memiliki pengaruh terhadap perilaku berdonasi. Ketika terjadi interaksi antara jarak sosial dan perilaku berdonasi, pengaruh dari variabel bebas terhadap variabel terikat akan berbeda pada nilai variabel bebas yang berbeda pula. Mengacu pada konteks penelitian, ketika terjadi perubahan jarak sosial terhadap perilaku berdonasi, maka pengaruh dari identity fusion terhadap perilaku berdonasi akan berbeda pada tingkat jarak sosial yang berbeda pula.

Konteks Penelitian. Penelitian ini menggunakan lembaga amal sebagai penerima donasi. Hal ini didasari pada fenomena saat ini di Indonesia dimana perilaku berdonasi sudah mulai beralih dari donasi perseorangan kepada donasi terstruktur yang dikelola oleh lembaga amal. Berbicara donasi kepada lembaga amal, dari 20 negara besar Indonesia menempati posisi ketujuh dengan skor partisipasi keseluruhan $56 \%$, dan $75 \%$ untuk aspek berdonasi kepada lembaga amal (Charities Aid Foundation, 2016). Pada tahun 2014 dilaporkan sebanyak 139 juta masyarakat Indonesia memberikan sebagian uang mereka kepada lembaga amal, menempati posisi ketiga yang diikuti oleh Brazil dan Cina. Beberapa lembaga amal yang kerap mendapatkan donasi dalam jumlah yang cukup besar adalah Aksi Cepat Tanggap (ACT) dan Dompet Dhuafa Republika (DDR). Berdasarkan laporan keuangan kedua lembaga, pada tahun 2015 tercatat ACT menerima donasi hampir sebesar Rp 17 Milyar (Razikun Takosunaryo, 2015), dan Dompet Dhuafa Republika (Paul Hadiwinata, Hidajat, Arsono, Achmad, Suharli, \& Rekan, 2015) lebih dari Rp 300 Milyar di tahun yang sama.

Secara spesifik, penelitian ini menggunakan identitas agama sebagai dasar evaluasi kesamaan atau perbedaan latar belakang donator dan penerima donasi. Terkait dengan latar belakang agama, lembaga amal ACT dan DDR teridentifikasi sebagai organisasi nirlaba berbasiskan ajaran agama Islam. Dalam situsnya, tertera dengan jelas bahwa organisasi ini menerima dana ZISWAF (Zakat, Infaq, Shadaqah, Wakaf; Yayasan Dompet Dhuafa Republika, 2017). Meski tidak tertera secara jelas sebagai organisasi yang menganut prinsip yang sama, ACT juga memiliki program serupa "berbasis spiritual seperti Qurban, Zakat, dan Wakaf" (Aksi Cepat Tanggap, 2017). Berdasarkan data tersebut, peneliti mempunyai beberapa pertanyaan: Jika ada lembaga amal yang punya latar belakang non-islam, apakah masyarakat Indonesia yang mayoritas beragama islam (87,18\%; Badan Pusat Statistik, 2010) mau menyalurkan donasinya ke lembaga amal tersebut? Mengacu pada studi Ein-Gar \& Levontin (2013), jika ada perbedaan identitas (agama) antara donatur dengan target, seberapa besar donasi yang akan diberikan oleh donatur? Akankah ada perbedaan jumlah donasi yang diberikan ketika identitas donatur dan target sama dibandingkan ketika identitas donatur dan target berbeda? Pertanyaan-pertanyaan tersebut akan dijawab dalam studi ini. 


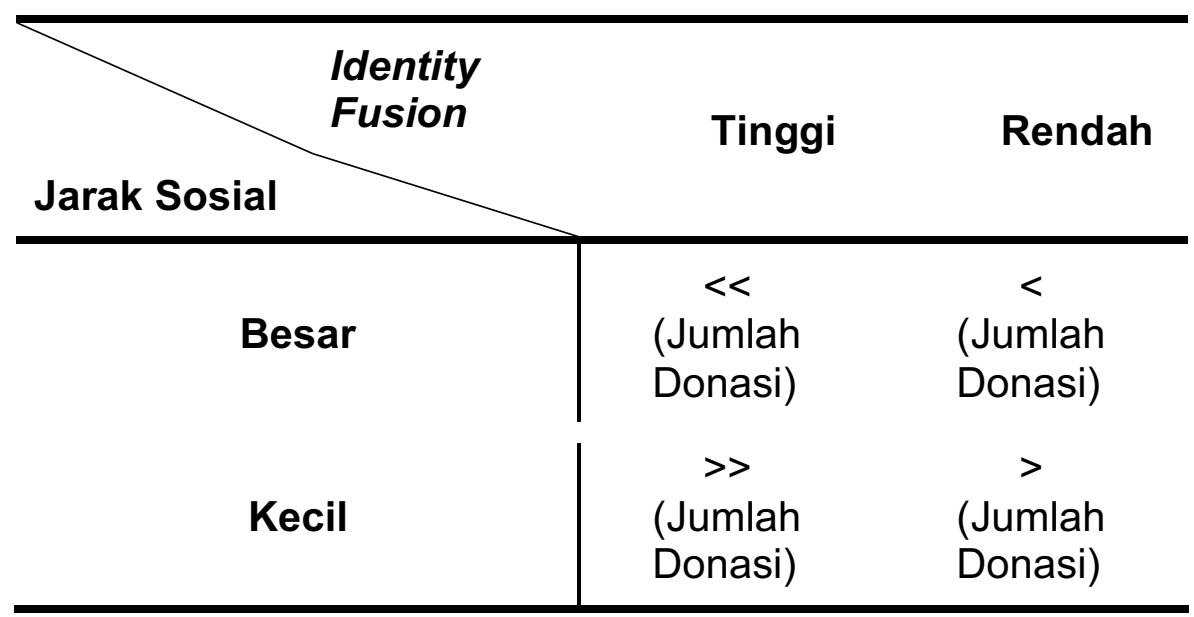

Gambar 1 Model hipotesis penelitian

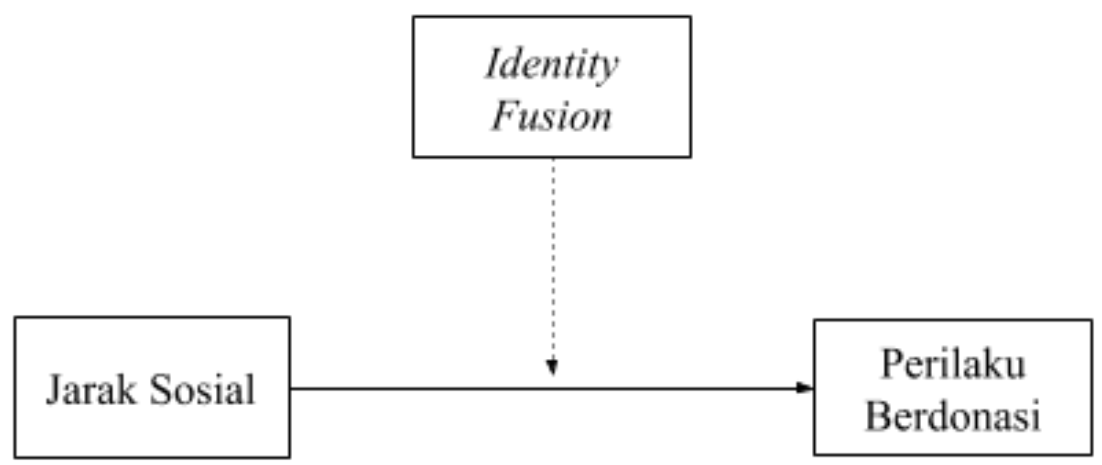

Grafik 1. Model desain penelitian

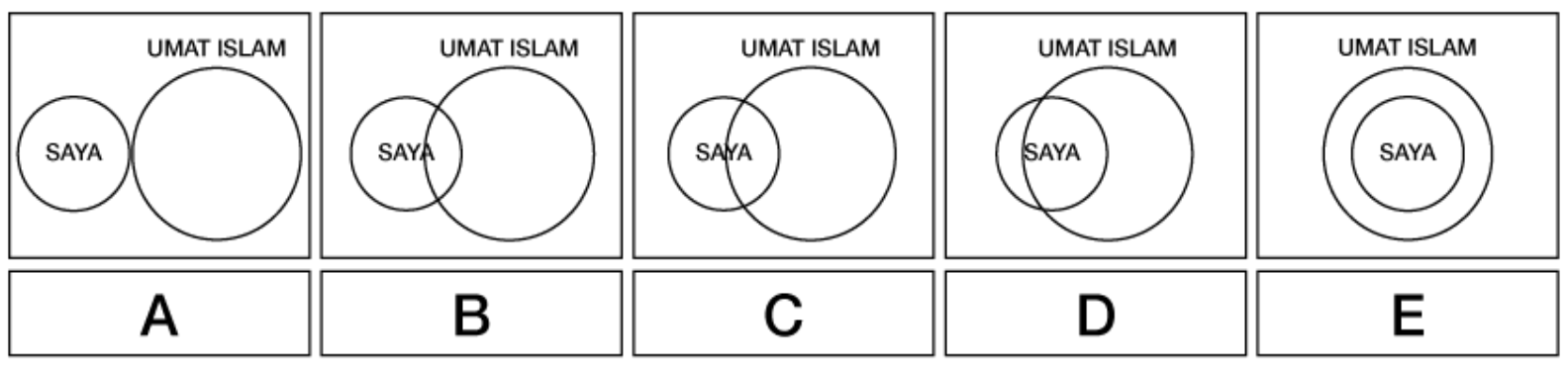

Gambar 2. Alat ukur Identity Fusion Pictorial Measure yang telah dimodifikasi

\section{Metode Penelitian}

Penelitian ini merupakan penelitian lanjutan dari studi Ein-Gar dan Levontin (2013). Penelitian ini menggunakan desain penelitian eksperimental untuk menguji kausalitas antar variabel. Desain penelitian ini adalah desain 2 (Jarak sosial: besar dan kecil) x 2 (identity fusion: kuat dan lemah) faktorial between subject.
Partisipan penelitian adalah mahasiswa aktif S1 Universitas Indonesia yang beragama Islam, dengan jumlah sampel pada pilot study sebanyak 40 mahasiswa (12 laki-laki, 28 perempuan) dan pada field study sebanyak 110 mahasiswa (46 laki-laki, 64 perempuan). Penulis merekrut partisipan dengan menggunakan metode convenience sampling, yaitu pengambilan partisipan berdasarkan ketersediaan dan keinginan individu untuk berpartisipasi 
dalam penelitian (Gravetter \& Forzano, 2011).

Prosedur Penelitian. Penelitian diawali dengan studi pilot. Pilot study dilakukan untuk menguji prosedur yang telah disusun, mencatat durasi rata-rata satu sesi eksperimen, memeriksa efektivitas dari instrumen pengukuran secara keseluruhan termasuk manipulasi bacaan dan alat ukur distractor. Terdapat 40 partisipan yang terlibat dalam penelitian ini, dan masing-masing kelompok memiliki sampel sebanyak 20 orang. Setelah dihitung, durasi rata-rata satu sesi eksperimen adalah 20 menit. Instrumen pengukuran dinilai cukup efektif dalam mengukur variabel jarak sosial dan identity fusion. Manipulasi bacaan terbukti dapat memanipulasi jarak sosial antara individu dan lembaga amal. Sebelum melakukan debrief di setiap akhir sesi eksperimen, penulis menanyakan kepada para partisipan variabel apa saja yang diteliti dalam penelitian ini. Terdapat beberapa jawaban yang dilontarkan dan diantaranya hampir tepat, seperti perilaku prososial, altruisme, dan lain-lain.

Setelah melakukan studi pilot, peneliti melakukan pengambilan data. Pembagian partisipan dilakukan secara acak untuk dibagi ke dalam kelompok eksperimen atau kontrol. Sebelum memulai eksperimen, partisipan diminta untuk mengisi lembar persetujuan yang telah disediakan. Setelah itu, partisipan diminta untuk mengisi kuesioner yang terdiri dari empat bagian: 1) manipulasi bacaan; 2) alat ukur distraktor Distress Subjective Scale milik Horowitz yang telah diadaptasi dalam Bahasa Indonesia (Izzati, 2017); 3) alat ukur distraktor WellBeing Scale milik Ryff yang telah diadaptasi juga dalam Bahasa Indonesia (Putri, 2012); 4) alat ukur Identity Fusion Pictorial Measure milik Swann dkk. (2009) yang telah diadaptasi Terdapat satu perbedaan kuesioner pada kelompok kontrol dan eksperimen, yaitu lembaga amal yang tertera pada manipulasi bacaan; kelompok eksperimen mendapatkan lembaga amal Yayasan Senyum Bunda
Theresa, dan pada kelompok kontrol Yayasan Senyum Azzikra. Semua partisipan mengerjakan kuesioner secara bersama-sama. Setelah itu, eksperimenter memberikan amplop reward yang berisi 4 lembar uang $\mathrm{Rp} 5000$, dan amplop donasi yang tidak berisi uang. Partisipan diberikan pilihan untuk menyimpan semua uang dalam amplop reward atau mendonasikannya sebagian ke dalam amplop donasi. Terakhir yang diberikan eksperimenter berupa alat ukur mengenai jarak sosial, setelah itu maka eksperimenter melakukan debrief penelitian.

\section{Hasil Penelitian}

Tabel 1 menyajikan hasil statistik deskriptif penelitian ini. Uji independent sample t-test seperti yang disajikan di tabel 2 menunjukkan bahwa terdapat perbedaan skor jarak sosial yang signifikan $(t(108)=-2,776, p=0,006)$ antara kelompok eksperimen $(M=3,393 ; \quad S D=1,498)$ dan kelompok kontrol $(M=4,111 ; S D=1,192)$. Berdasarkan hasil tersebut, manipulasi penelitian dikatakan berhasil. perbedaan jumlah skor rata-rata donasi antara kelompok eksperimen $(\mathrm{M}=2,43, \mathrm{SD}=1,45)$ dan kelompok kontrol $(\mathrm{M}=2,24 ; \mathrm{SD}=1,53)$ tidak signifikan secara statistik $(\mathrm{t}(108)=$ $0,661, p=0,51)$. Lebih lanjut, perbedaan jumlah donasi antara kelompok eksperimen $(\mathrm{M}=12142,86, \mathrm{SD}=7252,41)$ dan kelompok kontrol $(M=11203,70 ; S D=7643,91)$ tidak signifikan secara statistik $(\mathrm{t}(108)=0,661$, $p=0,51)$. Partisipan dalam kelompok eksperimen memberikan donasi rata-rata sebesar Rp 12.143 kepada lembaga amal, sedangkan partisipan dalam kelompok kontrol sebesar Rp 11.204.

Analisis utama penelitian dilakukan dengan menggunakan PROCESS MACRO Model 1 yang dikembangkan oleh Hayes (2016) dengan menggunakan 5,000 bootstrapped samples. Sebelum analisis dilakukan, karena variabel prediktor merupakan data kategorikal, skor variabel prediktor diubah menjadi dummy coding terlebih dahulu. Dalam analisis, data usia dan jenis kelamin dikontrol. Seperti yang dapat dilihat di tabel $3,15,30 \%$ varians 
Tabel 1. Hasil uji korelasi zero order dan statistik deskriptif

\begin{tabular}{lccccccccc}
\hline & & $\mathbf{M}$ & SD & \multicolumn{2}{c}{$\mathbf{1}$} & \multicolumn{2}{c}{$\mathbf{2}$} & \multicolumn{2}{c}{ 3 } \\
\hline 1. Jarak Sosial & KK & 4,111 & 1,192 & - & - & $0,201^{*}$ & $0,201^{*}$ & 0,068 & 0,068 \\
& KE & 3,393 & 1,498 & & & & & & \\
2. Fusion Identity & KK & 3,173 & 1,178 & $0,198^{*}$ & $-0,198^{*}$ & - & - & 0,114 & 0,114 \\
& KE & 3,173 & 1,178 & & & & & & \\
3. Donasi & KK & 2,24 & 1,53 & $-0,063$ & 0,063 & 0,114 & 0,114 & - & - \\
& KE & 2,43 & 1,45 & & & & & & \\
\hline
\end{tabular}

${ }^{* * *} p<.001 ; p<.05$

Tabel 2. Hasil uji independent sample t-test variabel jarak sosial dan donasi

\begin{tabular}{llcccc}
\hline Variabel & Kelompok (N) & Mean & SD & $t$ & $\mathrm{p}$ \\
\hline Jarak Sosial & Eksperimen (56) & 3,393 & 1,498 & $-2,776$ & 0,006 \\
& Kontrol (54) & 4,111 & 1,192 & & \\
\multirow{2}{*}{ Donasi } & Eksperimen (56) & 2,43 & 1,45 & 0,661 & 0,51 \\
& Kontrol (54) & 2,24 & 1,53 & & \\
\hline
\end{tabular}

Tabel 3. Model Regresi Perilaku Donasi

\begin{tabular}{lccccc}
\hline & $b$ & $\mathrm{SE}$ & $\mathrm{t}$ & $\mathrm{p}$ & $95 \% \mathrm{Cl}$ \\
\hline Identity Fusion & $-0,059$ & 0,123 & $-0,479$ & 0,633 & $-0,302,0,185$ \\
Jarak Sosial & $-0,248$ & 0,185 & $-1,343$ & 0,182 & $-0,615,0,118$ \\
IF*SD & 0,456 & 0,187 & 2,443 & 0,016 & $0,086,0,826$ \\
Usia & 0,137 & 0,085 & 1,616 & 0,109 & $-0,031,0,306$ \\
Jenis Kelamin & 0,442 & 0,187 & 2,365 & 0,020 & $0,071,0,812$ \\
\hline
\end{tabular}

$$
F(5,104)=3,756, p=0,004, R^{2}=0,153
$$

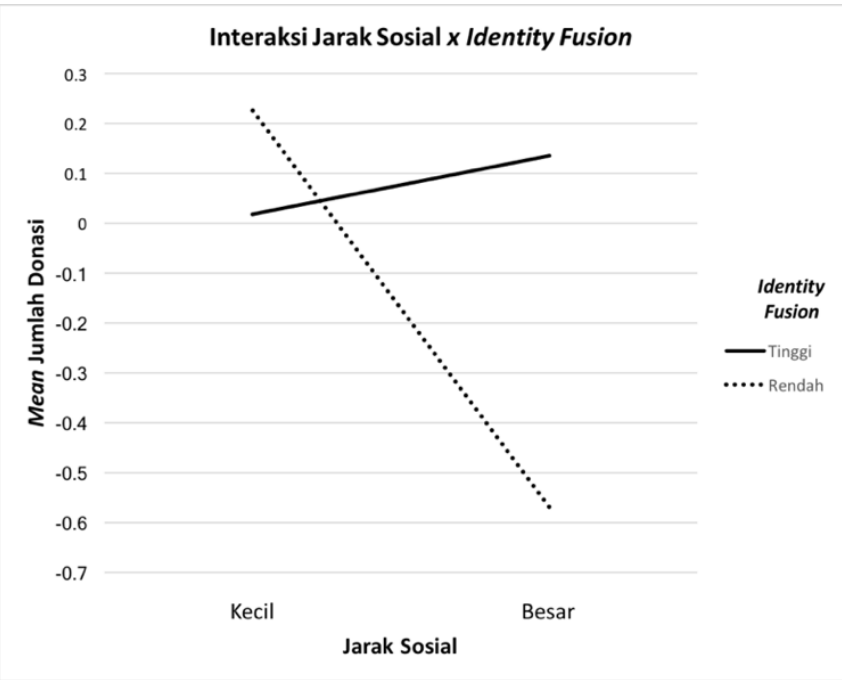

Grafik 2. Hasil analisis simple plot 
perilaku berdonasi dapat dijelaskan oleh jarak sosial, $F(5,104)=3,756, p=0,04$. Jarak sosial $(b=-0,248, S E=0,185,95 \%$ Cl $[-0,615,0,118], t=-1,343, p=0,182)$, identity fusion $(b=-0,059, \quad S E=0,123$, $95 \%$ Cl $(-0,302,0,185], t=-0,479, p=$ $0,633)$, dan usia $(b=0,137, S E=0,085$, $95 \%$ Cl $[-0,031,0,306], t=1,616, p=$ $0,109)$ tidak memiliki significant unique effect terhadap perilaku berdonasi. Jenis kelamin $(b=0,442, S E=0,187,95 \% \mathrm{Cl}$ $[0,071,0,812], \quad t=2,365, \quad p=0,020)$ mempunyai significant unique effect terhadap perilaku berdonasi. Hal ini menunjukkan bahwa partisipan perempuan memberikan donasi yang lebih banyak daripada partisipan laki-laki. Berdasarkan hasil tersebut, maka dapat dikatakan bahwa hipotesis pertama yang diajukan penulis ditolak, yaitu tidak terdapat pengaruh yang signifikan dari jarak sosial terhadap perilaku berdonasi kepada lembaga amal.

Pada grafik 2 terlihat bahwa terdapat efek interaksi yang signifikan antara jarak sosial dan identity fusion terhadap perilaku berdonasi $(b=0,456$, $\mathrm{SE}=0,187,95 \%$ Cl $[0,086,0,826], \mathrm{t}=$ $2,443, p=0,016)$. Hal ini menunjukkan bahwa jarak sosial mempengaruhi perilaku berdonasi secara signifikan ketika tingkat identity fusion rendah $(b=-0,704$, SE= $0,268,95 \% \mathrm{Cl}[-1,235,-0,173], \mathrm{t}=-2,631$, $\mathrm{p}=0,010)$ tetapi tidak ketika tingkat identity fusion tinggi $(b=0,208$, SE= $0,258,95 \%$ Cl $[-0,303,0,719], t=0,806$, $p=0,422)$. Dimana jumlah donasi yang didapatkan lebih besar pada jarak sosial kecil (socially near) daripada jarak sosial besar (socially distant).

\section{Diskusi}

Hasil dari penelitian ini menunjukkan bahwa tidak terdapat pengaruh jarak sosial yang signifikan terhadap perilaku berdonasi kepada lembaga amal baik pada partisipan kelompok eksperimen maupun kelompok kontrol. Hal ini dapat dilihat melalui hasil analisis yang menunjukkan bahwa jarak sosial tidak memiliki significant unique effect terhadap perilaku berdonasi. Dengan kata lain, hipotesis pertama penulis dalam penelitian ini tidak diterima. Temuan ini berbeda dengan temuan sebelumnya yang menunjukkan bahwa jarak sosial mempengaruh perilaku donasi (Ein-Gar \& Levontin, 2013). Hal ini mungkin dapat dijelaskan oleh konteks penelitian yang berbeda, dimana pada penelitian ini penerima donasi yang digunakan adalah lembaga agama sementara pada penelitian sebelumnya menggunakan individu sebagai target penerima donasi.

Hasil penelitian ini menunjukkan bahwa hipotesis kedua penulis diterima, yaitu terdapat pengaruh interaksi yang signifikan dari identity fusion dengan jarak sosial terhadap perilaku berdonasi kepada lembaga amal. Penulis mengasumsikan bahwa terdapat aspek jarak sosial dalam proses meleburnya personal self dan group self individu. Mengacu pada jarak sosial, terdapat jarak yang sangat dekat antara personal self dan group self ketika individu telah melebur dengan kelompok, atau bahkan tidak ada jarak sama sekali. Seperti yang telah dijelaskan pada bagian sebelumnya, lapisan yang memisahkan personal self dan group self memiliki pori yang memungkinkan keduanya terikat dan terkoneksi dengan sangat kuat (Swann dkk., 2012). Karena koneksi dan ikatan yang kuat inilah individu terdorong untuk memunculkan extreme behavior, dimana individu rela mengorbankan nyawanya untuk menyelamatkan anggota kelompoknya (Swann dkk., 2009; Swann dkk., 2010a; Swann dkk., 2010b; Swann dkk., 2014a; Swann dkk., 2014b; Gómez dkk., 2011). Mengacu pada Construal Level Theory, penulis menduga bahwa ingroup dipersepsikan sebagai hal yang 'konkret', sehingga individu mempunyai informasi (knowledge) yang jelas bahwa ia akan membela orang-orang terdekatnya, yang dapat membuat individu tidak ragu untuk melakukan extreme behavior. Meski demikian, asumsi tersebut perlu diteliti lebih lanjut pada studi berikutnya.

Meski penelitian ini telah mampu menunjukkan efek fusion identity dalam 
hubungan jarak sosial dan perilaku donasi, perlu diakui bahwa penelitian ini masih memiliki batasan, terutama untuk menjelaskan mengapa jarak sosial tidak ditemukan memiliki efek individual terhadap perilaku donasi. Pertama, penulis menduga bahwa manipulasi bacaan yang penulis berikan kurang efektif dalam menciptakan jarak sosial. Hal ini dapat ditinjau dari penjelasan mengenai lembaga amal termasuk nama masing-masing yayasan, yang diduga memberikan priming yang kurang kuat kepada partisipan bahwa mereka merupakan bagian dari umat beragama (Kristen pada kelompok eksperimen, Islam pada kelompok kontrol). Dengan demikian, jarak sosial yang tercipta antara partisipan dalam kelompok eksperimen dan kelompok kontrol kurang salien. Selain itu, penulis juga menduga bahwa satu kesamaan tidak cukup untuk meningkatkan atau menurunkan jarak sosial pada partisipan. Dugaan ini diperkuat oleh temuan Liviatan, Trope, dan Liberman (2008) yang menunjukkan bahwa dengan memperbanyak kesamaan antar dua pihak, jarak sosial dapat menjadi lebih kecil. Studi oleh Winterich, Zhang dan Mittal (2012) juga memperlihatkan hasil yang serupa. Dalam studi tersebut, jarak sosial dimanipulasi dengan menyamakan atau membedakan identitas politik partisipan dan lembaga amal. Dalam sebuah skenario, misi dan manajemen pengelolaan uang lembaga amal dijelaskan; hal ini mencerminkan identitas politik lembaga amal tersebut (konservatif atau liberal). Sesuai dengan hipotesisnya, partisipan yang merasa identitas politiknya sama dengan lembaga amal memberikan donasi yang lebih banyak dibandingkan dengan partisipan yang merasa identitas politiknya berbeda. Berbeda dengan salah satu studi Ein-Gar dan Levontin (2013), jarak sosial diciptakan dengan membedakan jenis kelamin partisipan dan pihak yang membutuhkan (contoh: partisipan perempuan dan korban laki-laki). Jika dibandingkan dengan studi-studi tersebut, penulis menilai priming identitas agama dalam studi ini memiliki efek yang paling lemah untuk menciptakan jarak sosial dibandingkan dengan jenis kelamin dan identitas politik.

Kedua, penulis menduga bahwa sampel dalam penelitian ini kurang heterogen. Hal ini dapat dilihat bahwa 97,3 persen sampel merupakan mahasiswa dari Fakultas Psikologi Universitas Indonesia. Karena sampel yang didapat kurang heterogen, karakteristik yang dimiliki sampel dapat diasumsikan kurang beragam. Meski telah membuat kriteria bahwa semua partisipan harus beragama Islam, namun penulis tidak mengetahui dan tidak mengukur religiusitas partisipan. Hal ini diasumsikan setara oleh penulis, karena fokus utama pada variabel jarak sosial adalah persamaan identitas agama, bukan religiusitas. Namun, dalam meta analisis oleh Bekkers dan Wiepking (2007) terdapat studi-studi yang menunjukkan bahwa religiusitas individu berkorelasi dengan frekuensi berdonasi dan jumlah donasi yang diberikan. Studi oleh Ranganathan dan Henley (2008) juga menunjukkan bahwa religiusitas memiliki direct effect terhadap attitude towards helping others (AHO), dan $\mathrm{AHO}$ tersebut memiliki direct effect terhadap attitude towards charitable organizations (ACO).

\section{Kesimpulan}

Berdasarkan hasil analisis data yang telah dipaparkan pada bab 4, terdapat perbedaan jarak sosial yang signifikan antara partisipan dalam kelompok kontrol dan partisipan dalam kelompok eksperimen. Hal ini menunjukkan bahwa manipulasi yang dilakukan oleh penulis berhasil. Selanjutnya, dapat diketahui bahwa $15,30 \%$ varians perilaku berdonasi kepada lembaga amal dapat dijelaskan oleh jarak sosial, dengan mengontrol variabel usia dan jenis kelamin secara statistik. Lebih lanjut, diketahui bahwa jarak sosial, identity fusion, dan usia tidak memiliki pengaruh yang signfiikan terhadap perilaku berdonasi. Jenis kelamin memiliki pengaruh yang signifikan terhadap 
perilaku berdonasi, yang menunjukkan bahwa partisipan perempuan memberikan donasi yang lebih banyak daripada partisipan laki-laki. Berdasarkan temuantemuan tersebut, dapat disimpulkan bahwa hipotesis pertama penulis ditolak, yaitu tidak terdapat pengaruh jarak sosial yang signifikan terhadap perilaku berdonasi kepada lembaga amal.

Selain itu, terdapat interaction effect antara jarak sosial dan identity fusion terhadap perilaku berdonasi yang signifikan. Hal ini menunjukkan menunjukkan bahwa jarak sosial mempengaruhi perilaku berdonasi ketika tingkat identity fusion rendah dimana jumlah donasi yang didapatkan lebih besar pada jarak sosial kecil (socially near) daripada jarak sosial besar (socially distant), tetapi tidak ketika tingkat identity fusion tinggi. Berdasarkan temuan-temuan tersebut, dapat disimpulkan bahwa hipotesis kedua penulis diterima, yaitu terdapat pengaruh interaksi dari jarak sosial dengan identity fusion yang signifikan terhadap perilaku berdonasi kepada lembaga amal.

\section{Daftar Pustaka}

Aksi Cepat Tanggap (2017). Tentang Kami: Sejarah Singkat. act.id: Diakses dari https://act.id/tentang/sejarah

Badan Pusat Statistik. (2010). Penduduk Menurut Wilayah dan Agama yang Dianut. Diakses dari http://sp2010.bps.go.id/index.php/sit e/tabel?tid $=321$

Bekkers, R., \& Wiepking, P. (2007). Generosity and Philanthropy: $A$ Literature Review. Diunduh dari Science of Generosity, University of Notre Dame: Diakses dari http://generosityresearch.nd.edu/ass ets/17402/generosity_and_philanthr opy_revised.pdf

Charities Aid Foundation. (2016). CAF World Giving Index 2016: The world's leading study of generosity. Diunduh pada 6 Januari, 2017 dari https://www.cafonline.org/docs/defa ult-source/about-us- publications/caf_worldgivingindex20 15_report.pdf?sfvrsn=2

Dompet Dhuafa Republika. (2017). About us: Sejarah. dompetdhuafa.org: Diakses dari http://www.dompetdhuafa.org/about

Ein-Gar, D., \& Levontin, L. (2013). Giving from a distance: Putting the charitable organization at the center of the donation appeal. Journal of Consumer Psychology, 23(2), 197211. doi:10.1016/j.jcps.2012.09.002

Fredman, L. A., Buhrmester, M. D., Gómez, A., Fraser, W. T., Talaifar, S., Brannon, S. M., \& Swann, W. B. (2015). Identity fusion, extreme pro-group behavior, and the path to defusion. Social and Personality Psychology Compass, 9(9), 468480. doi:10.1111/spc3.12193

Gravetter, F. J. \& Forzano, L. B. (2011). Research methods for the Behavioral Science (4th ed.). Wadsworth: Cengage Learning.

Hayes, A. F. (2016). PROCESS (Version 2.16.3) [Peranti Lunak]. Tersedia di http://www.processmacro.org/downl oad.html

Izzati, S. (2017). Pengaruh Pengungkapan Emosional Tertulis Terhadap Distres Subjektif Dan Suasana Hati Individu Yang Mengalami Putus Cinta. (Skripsi) Depok: Fakultas Psikologi Universitas Indonesia.

Liberman, N., Trope, Y., \& Stephan, E. (2007). Psychological distance. In A. W. Kruglanski, \& E. T. Higgins (Eds.), Social psychology: Handbook of basic principles. New York: Guilford Press.

Liviatan, I., Trope, Y., \& Liberman, N. (2008). Interpersonal similarity as a social distance dimension: Implications for perception of others' actions. Journal of Experimental Social Psychology, 44(5), 1256-1269. doi:10.1016/j.jesp.2008.04.007

Paul Hadiwinata, Hidajat, Arsono, Achmad, Suharli, \& Rekan. (2015). Laporan Posisi Keuangan Yayasan Dompet Dhuafa Republika 
Tahun 2015. Diunduh dari http://www.dompetdhuafa.org//uploa ds/media/LK-2015.pdf

Putri, F. O. (2012). Hubungan Antara Gratitude Dan Psychological WellBeing Pada Mahasiswa. (Skripsi) Depok: Fakultas Psikologi Universitas Indonesia.

Pryor, J. B., Reeder, G. D., Monroe, A. E., \& Patel, A. (2010). Stigmas and Prosocial Behavior: Are People Reluctant to Help Stigmatized Persons? Dalam Stürmer, S., \& Snyder, M., The Psychology of Prosocial Behavior: Group Processes, Intergroup Relations, and Helping (59-80). West Sussex, PO: John Wiley \& Sons.

Ranganathan, S. K., \& Henley, W. H. (2008). Determinants of charitable donation intentions: a structural equation model. International Journal of Nonprofit and Voluntary Sector Marketing, 13(1), 1-11. doi:10.1002/nvsm.297

Razikun Takosunaryo. (2015). Laporan Posisi Keuangan Yayasan Aksi Cepat Tanggap Tahun 2015. Diunduh dari https://act.id/upload/laporan_keuang an/audit_report_tahun_20151_2017 02190816.pdf

Small, D. A., Loewenstein, G., \& Slovic, P. (2007). Sympathy and callousness: The impact of deliberative thought on donations to identifiable and statistical victims. Organizational Behavior and Human Decision Processes 102 (2007) 143-153. doi: 10.1016/j.obhdp.2006.01.005

Swann Jr., W. B., Gómez, Á., Seyle, D. C., Morales, J., \& Huici, C. (2009). Identity fusion: the interplay of personal and social identities in extreme group behavior. Journal of Personality and Social Psychology, 96(5), 995. doi:10.1037/a0013668

Swann Jr, W. B., Gómez, Á., Dovidio, J. F., Hart, S., \& Jetten, J. (2010a).
Dying and killing for one's group: Identity fusion moderates responses to intergroup versions of the trolley problem. Psychological Science, 21(8), 1176-1183. doi:10.1177/0956797610376656

Swann Jr., W. B., Gómez, A., Huici, C., Morales, J., \& Hixon, J. G. (2010b). Identity fusion and self-sacrifice: Arousal as a catalyst of pro-group fighting, dying, and helping behavior. Journal of Personality and Social Psychology, 99(5), 824. doi:10.1037/a0020014

Swann Jr, W. B., Jetten, J., Gómez, A., Whitehouse, H., \& Bastian, B. (2012). When group membership gets personal: A theory of identity fusion. Psychological Review, 119(3), 441. doi:10.1037/a0028589

Swann Jr., W. B., Gómez, Á., Buhrmester, M. D., López-Rodríguez, L., Jiménez, J., \& Vázquez, A. (2014a). Contemplating the ultimate sacrifice: Identity fusion channels pro-group affect, cognition, and moral decision making. Journal of Personality and Social Psychology, 106(5), 713. doi:10.1037/a0035809

Swann Jr., W. B., Buhrmester, M. D., Gómez, A., Jetten, J., Bastian, B., Vázquez, ... Zhang, A. (2014b). What makes a group worth dying for? Identity fusion fosters perception of familial ties, promoting self-sacrifice. Journal of Personality and Social Psychology, 106(6), 912-926. doi:10.1037/a0036089

Swann Jr., W. B., \& Buhrmester, M. D. (2015). Identity Fusion. Current Directions in Psychological Science, 24(1), 52-57. doi:10.1177/0963721414551363

Winterich, K. P., Mittal, V., \& Ross, W. T. (2009). Donation behavior toward in-groups and out-groups: The role of gender and moral identity. Journal of Consumer Research, 36(2), 199-214. doi:10.1086/596720 